\title{
Vegetative development and flowering of Encyclia hybrid based on fertilization and substrate
}

\author{
Fernanda Jaqueline Menegusso $^{1}$ (D), Fabíola Villa ${ }^{1 *}$ (D), Tatiane Eberling ${ }^{1}$ (), Luciana Sabini da Silva ${ }^{1}$ (D), \\ Giovana Ritter ${ }^{1}\left(\mathbb{D}\right.$, Daniel Fernandes da Silva ${ }^{1}$ () \\ ${ }^{1}$ Universidade Estadual Oeste do Paraná, Marechal Cândido Rondon-PR, Brazil.
}

\begin{abstract}
Due to the fact that the western region of Parana is considered subtropical, with high temperatures in the summer, the hybrids of Encyclia are commercialized by the beauty of its flowers and durability. However, there are no studies involving potted plants, substrate types and fertilizers, as well as hybrids, for the genus Encyclia. Thus, the objective of this work was to evaluate the vegetative development and flowering of Encyclia based on fertilization and substrate. The experiment was conducted in a commercial orchard, from January to September/2017. The seedlings remained in a protected environment, with $50 \%$ shading. The experimental design was randomized blocks, in a 4 x 5 factorial scheme (substrates x fertilization intervals), with 4 replicates per treatment, and 4 pots per replicate. The lot chosen was sowed in vitro, with the hybrid Encyclia "Kropp" x E. atropurpurea. After five months of the last fertilization, the evaluations related to vegetative development and flowering were carried out. Substrates based on sphagnum presented better results in flowering. Organic fertilizations with Bokashi at 45 days after transplant (DAT) favor flowering and vegetative development of the Encyclia hybrid, which occurs in pots containing sphagnum-based substrates and with organic fertilizers above 60 DAT.
\end{abstract}

Keywords: Orchidaceae; nutrition; sphagnum.

\section{Resumo}

Desenvolvimento vegetativo e florescimento de um híbrido de Encyclia baseado na fertilização e no substrato Como a região oeste do Paraná é considerada subtropical, com altas temperaturas no verão, os híbridos de Encyclia são comercializados pela beleza de suas flores e durabilidade. No entanto, não existem estudos envolvendo plantas em vasos, tipos de substratos e fertilizantes, além dos híbridos para o gênero Encyclia. Diante do exposto, o objetivo deste trabalho foi avaliar o desenvolvimento vegetativo e o florescimento de Encyclia com base na adubação e no substrato.O experimento foi conduzido em um produtor comercial, de janeiro a setembro de 2017. As mudas permaneceram em ambiente protegido com $50 \%$ de sombreamento. O delineamento experimental foi em blocos casualizados, em esquema fatorial 4 x 5 (substratos x intervalos de fertilização), com 4 repetições por tratamento e 4 vasos por repetição. O lote escolhido era oriundo de semeadura in vitro, com o híbrido Encyclia "Kropp" x E. atropurpurea. Após cinco meses da última fertilização, foram realizadas avaliações relacionadas ao desenvolvimento vegetativo e floração. Os substratos à base de esfagno apresentaram melhores resultados no florescimento. As adubações orgânicas com Bokashi aos 45 dias após o transplante (DAT) favorecem a floração e o desenvolvimento vegetativo do híbrido de Encyclia, ocorrendo em vasos contendo substratos à base de esfagno e com adubações orgânicas acima de 60 DAT.

Palavras-chave: Orchidaceae; nutrição; esfagno.

\section{Introduction}

The subtribe Laeliinae is restricted to the Neotropical region, and comprises about 1,913 species, distributed in 40 genera (Chase et al., 2015). Genres such as
Brassavola, Cattleya, Guarianthe and Rhyncholaelia have extraordinary ornamental value. Others, such as Encyclia, Epidendrum (larger genus of the group) and Prosthechea, are common floristic elements of the Neotropics (Bastos et al., 2018).

\section{*Corresponding author: fvilla2003@hotmail.com}


The genus Encyclia presents approximately 120 species, distributed throughout the United States, Mexico, Brazil and Argentina. Brazil is home to 56 species, of which 42 are endemic (Arrigoni-Blank et al., 2015), with a high geographical distribution (Pansarin and Pansarin, 2010).

The species are generally epiphytic plants, but there are many rupicolous and rare terrestrials (Arrigoni-Blank et al., 2015). Encyclia has long, lanceolate and coriaceous leaves, 30-40 cm erect inflorescence with small fragrant flowers, with varied sepals, petals and lip colors. The lip is usually free, extending into a large, wing-shaped wolf. Encyclia hybrids "Kropp" x E. atropurpurea usually have petals and sepals of purple color and pink lip. It has grouped pseudobulbs, which, in nature, form clumps. The species vegetates in places with high luminosity and good ventilation. Packed, the plants support very high temperatures and luminosity (Meisel et al., 2014).

Due the fact that the western region of Paraná is considered subtropical, with high temperatures in the summer, the hybrids of Encyclia are cultivated at orchid nurseries and commercialized by the beauty and durability of its flowers. However, there are no studies involving potted plants, substrate types and fertilizers, as well as hybrids. For the commercial production of orchids, it is essential to use a substrate that allows greater growth of the seedlings (Villa et al., 2007; Mengarda et al., 2017). Epiphytic orchids grown in pots grow best on substrates with relatively thick texture and free drainage, giving the roots free access, as in natura (Santos and Smozinski, 2015).

For orchid cultivation, the substrate structure should show little change during the plant growing time in a pot, and its fragmentation, due to the decomposition, is undesirable because it forms a compact assembly, which can cause loss in the porosity necessary for the aeration of the plant's roots. It is also important that the substrate meets some chemical and nutritional requirements; for example, $\mathrm{pH}$ should be adequate, thus avoiding nutrient unavailability and nutritional imbalance (Faria et al., 2018).

There are numerous substrates that can be used in the packaging of orchids, such as Pinus bark, coconut fiber, coconut powder, piaçava fiber, carbonized rice husk, vermiculite, charcoal, styrofoam, among others. The substrate used should have satisfactory characteristics regarding water economy, aeration, permeability, buffering power for $\mathrm{pH}$ values and capacity for nutrient retention (Mirani et al., 2017; Silva et al., 2017).

Orchid growers adopt a variety of fertilization practices, with a wide range of fertilizers and innumerable combinations and formulations of organic fertilizers (Hoshino et al., 2016a). Organic fertilization has the advantages of gradual release of nutrients, increase in biological activity and greater nutrient diversity, besides being composed of products made with the use of residues (Naik et al., 2009; Ichinose et al., 2018). In view of the above, the objective of this work was to evaluate different substrates and fertilization intervals in the vegetative development and flowering of an Encyclia hybrid.

\section{Material and Methods}

The experiment was conducted in a commercial production greenhouse, and the seedlings remained in a protected environment, placed on wood slatted bench, with $50 \%$ shading.

The experimental design was randomized blocks, in a 4 x 5 factorial scheme (4 substrates x 5 organic fertilization intervals), resulting in 20 treatments, with 4 replicates per treatment, and each replicate composed of 4 pots, totaling 320 plants. The lot chosen was sowed in vitro, with the hybrid Encyclia "Kropp" x E. atropurpurea. The substrate used was: substrate of fine granulometry substrate; 33\% charcoal and 67\% Pinusbark; sphagnum + charcoal + Pinus bark, in ratio $1: 2 \mathrm{v}: \mathrm{v}$; sphagnum + substrate: $33 \%$ coal and $67 \%$ Pinus bark, in the ratio $2: 1 \mathrm{v}: \mathrm{v}$; and $100 \%$ sphagnum. Substrate characteristics are shown in Tables 1 and 2 (Embrapa, 1997). Fertilizations were done with the organic fertilizer Bokashi (Table 1), applying $3 \mathrm{~g}$ of the product on the side of the pot at intervals of $30,45,60,75$ and 90 days after transplanting (DAT). The application occurred only once, considering the time after transplantation, with the same final amount in all treatments.

Table 1. Chemical and physical analysis, with average values of hydrogen potential ( $\mathrm{pH}$ ), electrical conductivity (EC), water buffering capacity (WBC) and substrate/Bokashi density (D).

\begin{tabular}{|l|c|c|c|c|}
\hline Substrate & $\mathbf{p H}$ & $\mathbf{E C}\left(\mu \mathbf{S ~} \mathbf{~ c m}^{-1}\right)$ & $\mathbf{W B C}\left(\mathbf{m L} \mathbf{L}^{-1}\right)$ & $\mathbf{D}\left(\mathbf{g ~ c m}^{-3}\right)$ \\
\hline $33 \%$ charcoal + 67\% Pinus bark & $4.45 *$ & 66.90 & 498.45 & 0.16 \\
\hline Sphagnum + 33\% charcoal + 67\% Pinus bark (in ratio 1:2, v:v) & 4.50 & 102.23 & 502.88 & 0.14 \\
\hline Sphagnum + 33\% charcoal + 67\% Pinus bark (in ratio 2:1, v:v) & 4.80 & 80.94 & 465.76 & 0.04 \\
\hline 100\% sphagnum & 5.30 & 94.80 & 518.06 & 0.02 \\
\hline CV (\%) & 20.08 & 18.54 & 10.69 & 22.73 \\
\hline Bokashi & 6.12 & 1.71 & 5.39 & 0.005 \\
\hline
\end{tabular}

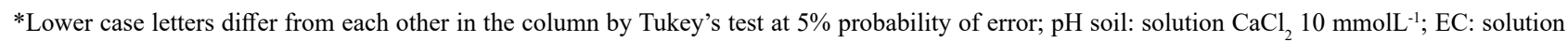
0,$5 ; 2,0 ; 3,5 ; 5,0$ and $6,5 \mathrm{dS} \mathrm{m}^{-1}$, methods were: solution extractor and "pourthru"; D: Embrapa (1997). 
Table 2. Chemical analysis, with average values of the nutrients found in the substrates.

\begin{tabular}{|c|c|c|c|c|c|c|c|}
\hline \multirow{2}{*}{ Substrate } & $\mathbf{N}$ & $\mathbf{P}$ & $\mathbf{K}$ & $\mathbf{C a}$ & Mg & B & $\mathbf{F e}$ \\
\hline & \multicolumn{5}{|c|}{ 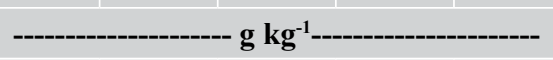 } & \multicolumn{2}{|c|}{--- $\mathrm{mg} \mathrm{kg}^{-1}----$} \\
\hline $33 \%$ charcoal $+67 \%$ Pinus bark & 0.3 & 0.1 & 0.60 & 0.20 & 0.1 & 5.6 & 15.6 \\
\hline Sphagnum $+33 \%$ charcoal $+67 \%$ Pinus bark (in ratio $1: 2, \mathrm{v}: \mathrm{v}$ ) & 0.3 & 0.1 & 0.55 & 0.19 & 0.1 & 5.4 & 15.5 \\
\hline Sphagnum $+33 \%$ charcoal $+67 \%$ Pinus bark (in ratio $2: 1, \mathrm{v}: \mathrm{v}$ ) & 0.2 & 0.1 & 0.56 & 0.18 & 0.1 & 5.1 & 15.3 \\
\hline $100 \%$ sphagnum & 0.8 & 0.1 & 0.50 & 0.10 & 0.1 & 4.1 & 16.0 \\
\hline Bokashi & 27.3 & 1.67 & 9.53 & 6.22 & 3.61 & --- & --- \\
\hline
\end{tabular}

Regarding the chemical characteristics of the substrates used (Table 1), it appears that all have $\mathrm{pH}$ values below 7 , with substrate composed of sphagnum being the one with the highest $\mathrm{pH}$ value. Another characteristic considered is the electrical conductivity (EC), which is the measure that is related to the number of ions present in the solution. The higher the value, the more electrical energy can be conducted between these ions, and the higher the value for EC. The values for EC varied among the substrates used, with the substrate composed of sphagnum + charcoal + Pinus bark and 100\% sphagnum having the highest values (both contain sphagnum in the composition).

The water holding capacity is linked to the irrigation management schedule. This information is useful to establish a balance between water available to plants and the aeration space for root development (Barbosa et al., 2018).

Also, according to Barbosa et al. (2018), the substrate density value is also important for the interpretation of other characteristics, such as porosity, aeration space and water availability, considering density values for substrate used in cells and trays between $0.1 \mathrm{~g} \mathrm{~cm}^{-3}$ and $0.3 \mathrm{~g} \mathrm{~cm}^{-3}$; for pots up to $15 \mathrm{~cm}$ high, from 0.25 to $0.4 \mathrm{~g} \mathrm{~cm}^{-3}$; for pots from 20 to $30 \mathrm{~cm}$, from 0.3 to $0.5 \mathrm{~g} \mathrm{~cm}^{-3}$; and for larger vessels, from 0.5 to $0.8 \mathrm{~g} \mathrm{~cm}^{-3}$.

The batch of plants was standardized in $40 \mathrm{~cm}$ of height and maintained in PVC pots 10 (diameter superior $10 \mathrm{~cm}$, inferior to $7.5 \mathrm{~cm}$ and height of $9 \mathrm{~cm}$ ). After 90 days, the plants were removed from these containers, the roots were cleaned - in order to remove the old substrate, and they were transplanted to vessels 14 (upper diameter $14 \mathrm{~cm}$, lower $9.5 \mathrm{~cm}$ and height $10.5 \mathrm{~cm}$ ), filled with the substrates corresponding to each treatment. The plants were kept centralized in the vessel, and, soon afterwards, were tutored with the help of wooden toothpicks.

The mixtures of substrates occurred in the commercial production greenhouse itself. The sphagnum went through previous hydration, remaining in a water tank after its decompression for later use.

During the experiment period, the plants were observed for pests and diseases, with the application of granulated molluscicide. Irrigation was daily and manual, whenever necessary, to increase the humidity of the substrate, with the same amount of water for all pots.

After five months of the last fertilization, the evaluations related to flowering were performed, such as number of flowers (counting), length of flower buds (mm), length of flower stems and length up to the first flower bud $(\mathrm{cm})$, flower bud diameter and flower bud color (preset color scale: green, more green than purple, and purple).

The vegetative development was evaluated through the number of pseudobulbs and roots (counting), diameter of the pseudobulbs $(\mathrm{mm})$, largest leaf $(\mathrm{cm})$ and length of the largest root $(\mathrm{cm})$. The parameters that needed to be measured were evaluated using a graduated ruler and/ or digital caliper. The means of the qualitative variables obtained were submitted to analysis of variance and were grouped by the Scott-Knott test to a 5\% probability of error, using statistical software Sisvar (Ferreira, 2019).

\section{Results and Discussion}

For the flowering parameters, number of flowers, length of flower stems and length up to the first floral bud, significance was only observed for the substrates used (Table 3).

Table 3. Number of flowers per stem (NF), length of floral stems (LFS) and length up to the first floral bud (LFFB) of Encyclia "Kropp" x E. atropurpurea, grown on different substrates*.

\begin{tabular}{|l|c|c|c|}
\hline Substrates & NF & $\begin{array}{c}\text { LFS } \\
(\mathbf{c m})\end{array}$ & $\begin{array}{c}\text { LFFB } \\
(\mathbf{c m})\end{array}$ \\
\hline $\begin{array}{l}\text { 33\% charcoal + 67\% Pinus bark } \\
\text { Sphagnum + 33\% charcoal +67\% }\end{array}$ & $2.09 \mathrm{a}$ & $4.37 \mathrm{a}$ & $14.86 \mathrm{~b}$ \\
\hline $\begin{array}{l}\text { Pinus bark (in ratio 1:2, v:v) } \\
\text { Sphagnum + 33\% charcoal + }\end{array}$ & $2.31 \mathrm{a}$ & $5.17 \mathrm{a}$ & $19.93 \mathrm{a}$ \\
\hline $\begin{array}{l}\text { 67\% Pinus bark (in ratio 2:1, v:v) } \\
\text { 100\% sphagnum }\end{array}$ & $2.09 \mathrm{a}$ & $4.37 \mathrm{a}$ & $18.26 \mathrm{a}$ \\
\hline CV (\%) & $4.70 \mathrm{a}$ & $17.27 \mathrm{a}$ \\
\hline
\end{tabular}

*Averages followed by the same lowercase letter in the column do not differ by Scott-Knott's test, 5\% error probability. For variables NF and LFS, transformation by square root of $\mathrm{Y}+1.0$.

There was no statistical difference for the number of flowers per stem (NF) and length of floral stems (LFS), indicating that these mixtures of substrates have the same behavior for potted orchids. For length up to the first floral bud (LFFB), the substrate composed of sphagnum 
+ charcoal + Pinus bark, sphagnum + charcoal + Pinus bark and sphagnum stood out, with no statistical difference between them and presenting higher values than the substrate composed only of charcoal + Pinus bark. The best results were for the compositions that contained sphagnum; thus we can conclude that this substrate is important in the composition of the mixture for a better development of the floral stem of Encyclia.

Another factor that may have influenced LFFB is the $\mathrm{pH}$ (Table 1), because the substrate composed of charcoal + Pinus barkhad a lower value for this characteristic.
According to Ludwig et al. (2014) and Hoshino et al. (2016b), the $\mathrm{pH}$ value is a chemical characteristic related to the availability of nutrients to plants. Inadequate values are detrimental, especially when there is excessive acidity, because, in these cases, smaller amounts of nutrients are available, and plants are subject to greater absorption of toxic elements, such as aluminium and manganese.

The interaction between the substrates and the organic fertilization intervals was significant for floral bud diameter (FBD), floral bud color (FB Color) and floral bud length (FBL) (Table 4).

Table 4. Floral bud diameter (FBD), floral bud color (FB Color), floral bud length (FBL) of Encyclia "Kropp" $\mathrm{x}$ E. atropurpurea, cultivated on substrates and submitted to organic fertilization in days after transplanting (DAT).

\begin{tabular}{|c|c|c|c|c|c|}
\hline \multirow{2}{*}{ Substrates } & \multicolumn{5}{|c|}{ Organic fertilization intervals } \\
\hline & 30 DAT & 45 DAT & 60 DAT & 75 DAT & 90 DAT \\
\hline \multicolumn{6}{|l|}{ FBD (mm) } \\
\hline $33 \%$ charcoal $+67 \%$ Pinus bark & $2.30 \mathrm{aA}^{*}$ & $2.20 \mathrm{bA}$ & $2.39 \mathrm{aA}$ & $2.16 \mathrm{aA}$ & $1.94 \mathrm{bA}$ \\
\hline Sphagnum $+33 \%$ charcoal $+67 \%$ Pinus bark (in ratio $1: 2, \mathrm{v}: \mathrm{v}$ ) & $2.12 \mathrm{aA}$ & $2.38 \mathrm{aA}$ & $2.30 \mathrm{aA}$ & $2.30 \mathrm{aA}$ & $2.25 \mathrm{bA}$ \\
\hline Sphagnum $+33 \%$ charcoal $+67 \%$ of Pinus bark (in ratio $2: 1, \mathrm{v}: \mathrm{v}$ ) & $2.59 \mathrm{aA}$ & $2.69 \mathrm{aA}$ & $2.27 \mathrm{aA}$ & $2.18 \mathrm{aA}$ & $2.54 \mathrm{aA}$ \\
\hline $100 \%$ sphagnum & $2.32 \mathrm{aA}$ & $1.98 \mathrm{bB}$ & $2.53 \mathrm{aA}$ & $2.65 \mathrm{aA}$ & $2.49 \mathrm{aA}$ \\
\hline $\mathrm{CV}(\%)$ & \multicolumn{5}{|c|}{26.57} \\
\hline \multicolumn{6}{|l|}{ FBL $(\mathrm{cm})$} \\
\hline $33 \%$ charcoal $+67 \%$ Pinus bark & $1.53 \mathrm{aA}$ & $1.59 \mathrm{aA}$ & $1.58 \mathrm{aA}$ & $1.54 \mathrm{aA}$ & $1.40 \mathrm{bA}$ \\
\hline Sphagnum $+33 \%$ charcoal $+67 \%$ Pinus bark (in ratio $1: 2, \mathrm{v}: \mathrm{v}$ ) & $1.48 \mathrm{aA}$ & $1.55 \mathrm{aA}$ & $1.66 \mathrm{aA}$ & $1.61 \mathrm{aA}$ & $1.52 \mathrm{bA}$ \\
\hline Sphagnum $+33 \%$ charcoal $+67 \%$ Pinus bark (in ratio $2: 1, \mathrm{v}: \mathrm{v}$ ) & $1.71 \mathrm{aA}$ & $1.73 \mathrm{aA}$ & $1.60 \mathrm{aA}$ & $1.54 \mathrm{aA}$ & $1.68 \mathrm{aA}$ \\
\hline $100 \%$ sphagnum & $1.58 \mathrm{aB}$ & $1.41 \mathrm{aB}$ & $1.70 \mathrm{aA}$ & $1.74 \mathrm{aA}$ & $1.71 \mathrm{aA}$ \\
\hline $\mathrm{CV}(\%)$ & \multicolumn{5}{|c|}{18.70} \\
\hline \multicolumn{6}{|l|}{ FB color } \\
\hline $33 \%$ charcoal $+67 \%$ Pinus bark & $1.77 \mathrm{aA}$ & $1.74 \mathrm{bA}$ & $1.67 \mathrm{aA}$ & $1.65 \mathrm{aA}$ & $1.59 \mathrm{aA}$ \\
\hline Sphagnum $+33 \%$ charcoal $+67 \%$ Pinus bark (in ratio $1: 2, v: v)$ & $1.74 \mathrm{aA}$ & $1.89 \mathrm{aA}$ & $1.88 \mathrm{aA}$ & $1.78 \mathrm{aA}$ & $1.75 \mathrm{aA}$ \\
\hline Sphagnum $+33 \%$ charcoal $+67 \%$ Pinus bark (in ratio $2: 1, \mathrm{v}: \mathrm{v}$ ) & $1.89 \mathrm{aA}$ & $2.07 \mathrm{aA}$ & $1.70 \mathrm{aB}$ & $1.66 \mathrm{aB}$ & $1.99 \mathrm{aA}$ \\
\hline $100 \%$ sphagnum & $1.75 \mathrm{aA}$ & $1.55 \mathrm{bA}$ & $1.87 \mathrm{aA}$ & $1.83 \mathrm{aA}$ & $1.85 \mathrm{aA}$ \\
\hline $\mathrm{CV}(\%)$ & \multicolumn{5}{|c|}{23.18} \\
\hline
\end{tabular}

*Averages followed by the same lowercase letter in the column and uppercase in the row do not differ by Scott-Knott's test, $5 \%$ error probability. For variables FBD, FB Color and FBL, transformation by square root of $\mathrm{Y}+1.0$.

The evaluated plants showed no difference in FBD between the substrates at 30,60 and 75 days after transplanting. Only the unfolding at 45 and 90 DAT showed a significant difference, with better results in substrate composed of sphagnum + charcoal + Pinus bark and sphagnum + charcoal + Pinus bark, and substrate composed of sphagnum + charcoal + Pinus bark and 100\% sphagnum, which demonstrates, once again, sphagnum superiority. In the unfolding of the significant interaction, the orchids, when fertilized at 45 DAT and cultivated in sphagnum and charcoal + Pinus bark, presented smaller diameter of the floral bud in comparison to the others evaluated intervals (Table 4).
The evaluated plants showed a significant difference in FBL among the organic fertilization intervals only in the $100 \%$ sphagnum substrate; at 30 and 45 DAT, the FBL was lower than the others intervals. Among the substrates, the evaluated plants showed that charcoal + Pinus bark and sphagnum + charcoal + Pinus bark presented lower FBL in comparison to sphagnum + charcoal + Pinus bark and $100 \%$ sphagnum at 90 DAT (Table 4). Larger diameters and lengths of floral buds result in larger flowers, which are important variables in the commercialization of Encyclia vessels.

FB Color showed significant difference among the substrates only at 45 DAT; the substrate composed of 
charcoal + Pinus bark and sphagnum presented lower values than the other substrates. There was a difference between the DATs only for the substrate composed of sphagnum + charcoal + Pinus bark; at 60 and 75 DAT, the FB color is lower in comparison to the other intervals evaluated (Table 4).

Several aspects are considered important in the commercial evaluation of the quality of orchid flowers, such as number and size of flower buds and diameter of flowers. The genus Encyclia is little studied, and few works are described in the literature, but it is a plant of great interest, because it presents resistance to high temperatures and durability.

Only the substrates were significant for the NPB, NR and LLR (Table 5). For NPB, the substrates composed of sphagnum + charcoal + Pinus bark, sphagnum + charcoal + Pinus bark and $100 \%$ sphagnum stood out, presenting no statistical difference between them and being superior to charcoal + Pinus bark. The substrates composed of sphagnum + charcoal + Pinus bark, sphagnum + charcoal + Pinus bark and $100 \%$ sphagnum have sphagnum in their composition, which is an important moss, with ideal characteristics for the cultivation of epiphytic orchids (Sousa et al., 2015). Pseudobulbs are important plant organs of the Laeliinae subgroup, as they have reserves, such as carbohydrates and water, which supply the energetic demand of the flowers and guarantee the maintenance of the integrity of the inflorescence (Kimet al., 2016).

Table 5. Number of pseudobulbs (NPB), number of roots (NR) and length of the largest root (LLR) of Encyclia "Kropp" x E. atropurpurea, grown on different substrates*.

\begin{tabular}{|l|c|c|c|}
\hline Substrates & NPB & NR & $\begin{array}{c}\text { LLR } \\
(\mathbf{c m})\end{array}$ \\
\hline $\begin{array}{l}\text { 33\% charcoal + 67\% Pinus bark } \\
\text { Sphagnum + 33\% charcoal + 67\% }\end{array}$ & $2.93 \mathrm{~b}$ & $1.92 \mathrm{a}$ & $2.90 \mathrm{a}$ \\
\hline $\begin{array}{l}\text { Pinus bark (in ratio 1:2, v:v) } \\
\text { Sphagnum + 33\% charcoal + 67\% }\end{array}$ & $3.16 \mathrm{a}$ & $1.46 \mathrm{~b}$ & $2.08 \mathrm{c}$ \\
\hline $\begin{array}{l}\text { Pinus bark (in ratio 2:1, v:v) } \\
100 \% \text { sphagnum }\end{array}$ & $3.24 \mathrm{a}$ & $1.53 \mathrm{~b}$ & $2.45 \mathrm{~b}$ \\
\hline CV (\%) & $3.15 \mathrm{a}$ & $1.32 \mathrm{~b}$ & $1.63 \mathrm{~d}$ \\
\hline
\end{tabular}

*Averages followed by the same lowercase letter in the column do not differ by Scott-Knott's test, $5 \%$ error probability. For variables NR and LLR, transformation by square root of $\mathrm{Y}+1.0$.

Regarding the physical characteristics (Table 1), what makes the acid $\mathrm{pH}$ of the substrate composed of charcoal + Pinus bark stand out even more is the electrical conductivity (EC), which showed lower values when compared to the other substrates used and could influence the rated characteristic.

For NR, the substrate composed of charcoal + Pinus bark excelled, being superior to charcoal + Pinus bark, sphagnum + charcoal + Pinus bark and sphagnum + charcoal + Pinus bark, presenting no statistical difference between them (Table 5), thus corroborating Dronk et al. (2012) in the study of a hybrid of Blassocattleya Bryce Canyon x Blc. Pamela Hetherington. Again, for LLR, the best substrate was charcoal + Pinus bark, differing statistically from the others. As the proportion of sphagnum in the mixture increased, the LLR appeared smaller. As this hybrid orchid is epiphytic, when it is cultivated in pots, the use of substrates of a slightly thicker texture and with free drainage, as in the case of substrate composed of charcoal + Pinus bark, helps the development of the plant, since the roots have free access to air and light, growing in all directions (Lone et al., 2008). Thus, substrates that do not exhibit good aeration tend to limit root development, as may have occurred on substrates containing sphagnum.

When it comes to the physical characteristics of the substrates, it is observed that the water buffering capacity (WBC) had a different value for charcoal + Pinus bark when compared to other substrates. In WBC, the substrate composed of charcoal + Pinus bark showed lower values than sphagnum + charcoal + Pinus bark and $100 \%$ sphagnum for this substrate characteristic. When evaluating LLR (Table 5), it is observed that substrate composed of charcoal + Pinus bark had a longer root length in relation to the other substrates. It can be said that, due to the fact that the substrate stores less water, the plant is forced to seek water, having a longer root length. The same logic can be applied to the number of bulbs: when there is storage of a smaller amount of water, the number of pseudobulbs also decreases with other substrates (Table 5).

Interaction between the substrates and the organic fertilization intervals were significant when the length of the largest leaf (LLL), diameter of the largest leaf (DLL) and diameter of the pseudobulb (DPB) were evaluated (Table 6).

For LLL, in the unfolding, there was no statistical difference between 30, 45, 75 and 90 DAT within the substrates. Packaged orchids containing sphagnum + charcoal + Pinus bark and fertilized at 60 DAT showed lower LLL than the other treatments. The substrate composed of sphagnum + charcoal + Pinus bark contains sphagnum in its composition, and therefore has an unfavorable physicochemical structure for the growth of the aerial part of the hybrid of Encyclia.

For DLL, there was statistical difference between substrates for plants fertilized at 30 and 45 DAT. Hoshino et al. (2016a), when studying organic fertilization in the development of orchid Cattlianthe "Chocolate drop", stated that Bokashi increases the number of pseudobulbs and leaves, and, consequently, their development and diameters; this was also observed in Laelia hybrid plants with use of this nutrition (Tejeda-Satorius et al., 2018).

Studies suggest that, during the period of vegetative growth, the use of fertilizers is a quick way to provide nutrients in periods of great demand, such as the vegetative development of plants, mainly potted orchids. 
Table 6. Length of the largest leaf (LLL), diameter of the largest leaf (DLL) and diameter of the pseudobulb (DPB) of Encyclia "Kropp" x E. atropurpurea, cultivated on substrates and submitted to organic fertilization in days after transplanting (DAT)*.

\begin{tabular}{|c|c|c|c|c|c|}
\hline \multirow{2}{*}{ Substrates } & \multicolumn{5}{|c|}{ Organic fertilization intervals } \\
\hline & 30 DAT & 45 DAT & 60 DAT & 75 DAT & 90 DAT \\
\hline \multicolumn{6}{|l|}{$\operatorname{LLL}(\mathrm{cm})$} \\
\hline $33 \%$ charcoal $+67 \%$ Pinus bark & $39.56 \mathrm{aA}^{*}$ & $36.07 \mathrm{aA}$ & $38.14 \mathrm{aA}$ & $38.73 \mathrm{aA}$ & $36.09 \mathrm{aA}$ \\
\hline Sphagnum $+33 \%$ charcoal $+67 \%$ Pinus bark (in ratio $1: 2, \mathrm{v}: \mathrm{v}$ ) & $39.96 \mathrm{aA}$ & $38.45 \mathrm{aA}$ & $22.74 \mathrm{bB}$ & $37.91 \mathrm{aA}$ & $38.81 \mathrm{aA}$ \\
\hline Sphagnum $+33 \%$ charcoal $+67 \%$ Pinus bark (in ratio $2: 1, \mathrm{v}: \mathrm{v}$ ) & $36.39 \mathrm{aA}$ & $39.03 \mathrm{aA}$ & $42.01 \mathrm{aA}$ & $36.42 \mathrm{aA}$ & $40.94 \mathrm{aA}$ \\
\hline $100 \%$ sphagnum & $37.59 \mathrm{aA}$ & $38.78 \mathrm{aA}$ & $35.53 \mathrm{aA}$ & $35.33 \mathrm{aA}$ & $37.75 \mathrm{aA}$ \\
\hline $\mathrm{CV}(\%)$ & \multicolumn{5}{|c|}{20.72} \\
\hline \multicolumn{6}{|l|}{$\operatorname{DLL}(\mathrm{mm})$} \\
\hline $33 \%$ charcoal $+67 \%$ Pinus bark & $8.96 \mathrm{bB}$ & $16.28 \mathrm{aA}$ & $17.54 \mathrm{aA}$ & $16.78 \mathrm{aA}$ & $16.58 \mathrm{aA}$ \\
\hline Sphagnum $+33 \%$ charcoal $+67 \%$ Pinus bark (in ratio $1: 2, \mathrm{v}: \mathrm{v}$ ) & $17.19 \mathrm{aA}$ & $11.37 \mathrm{bB}$ & $17.17 \mathrm{aA}$ & $16.83 \mathrm{aA}$ & $16.58 \mathrm{aA}$ \\
\hline Sphagnum $+33 \%$ charcoal $+67 \%$ Pinus bark (in ratio $2: 1, v: v$ ) & $16.71 \mathrm{aA}$ & $10.43 \mathrm{bB}$ & $17.59 \mathrm{aA}$ & $16.33 \mathrm{aA}$ & $18.28 \mathrm{aA}$ \\
\hline $100 \%$ sphagnum & $17.09 \mathrm{aA}$ & $15.99 \mathrm{aA}$ & $17.44 \mathrm{aA}$ & $15.16 \mathrm{aA}$ & $14.90 \mathrm{aA}$ \\
\hline $\mathrm{CV}(\%)$ & \multicolumn{5}{|c|}{26.20} \\
\hline \multicolumn{6}{|l|}{$\mathrm{DPB}(\mathrm{mm})$} \\
\hline $33 \%$ charcoal $+67 \%$ Pinus bark & $21.81 \mathrm{aB}$ & $23.56 \mathrm{aA}$ & $21.14 \mathrm{bB}$ & $24.43 \mathrm{aA}$ & $19.48 \mathrm{bB}$ \\
\hline Sphagnum $+33 \%$ charcoal $+67 \%$ Pinus bark (in ratio 1:2, v:v) & $23.06 \mathrm{aA}$ & $24.28 \mathrm{aA}$ & $22.57 \mathrm{bA}$ & $22.68 \mathrm{aA}$ & $26.38 \mathrm{aA}$ \\
\hline Sphagnum $+33 \%$ charcoal $+67 \%$ Pinus bark (in ratio $2: 1$, v:v) & $25.42 \mathrm{aB}$ & $25.38 \mathrm{aB}$ & $28.76 \mathrm{aA}$ & $25.30 \mathrm{aB}$ & $27.56 \mathrm{aA}$ \\
\hline $100 \%$ sphagnum & $24.65 \mathrm{aA}$ & $22.82 \mathrm{aB}$ & $24.39 \mathrm{bA}$ & $21.99 \mathrm{aB}$ & $26.70 \mathrm{aA}$ \\
\hline CV $(\%)$ & \multicolumn{5}{|c|}{18.45} \\
\hline
\end{tabular}

*Means followed by the same lowercase letter in the column and upper case in the row do not differ by Scott-Knott's test, $5 \%$ error probability.

\section{Conclusions}

Substrates based on sphagnum presented better results in flowering. Organic fertilizations with Bokashi at 45 DAT favor the floral bud diameter (Encyclia "Kropp" x $E$. atropurpurea). The substrate composed of charcoal + Pinus bark provides greater development of the root system and fewer pseudobulbs.

\section{Author Contribution}

FJM, FV, DFS: provided structure and conditions to develop the experiments, conducted the experiments. FJM, FV, DFS, TE, LSS, GR: wrote the manuscript, carried out the statistical analysis and contributed to the discussion of results. All the authors read and approved the final version of the paper.

\section{Acknowledgment}

The authors are thankful to Coordenação de Aperfeiçoamento de Pessoal de Nível Superior (CAPES) Brazil for granting scholarship.

\section{References}

ARRIGONI-BLANK, M.F.; SANTOS, M.S.; BLANK, A.F.; RABBANI, A.R.C.; SILVA-MANN, R.; SANTOS,
J.B.; COSTA, A.S.; MENEZES, T.S.A. Analysis of genetic diversity of Laeliinae (Orchidaceae) in the State of Sergipe using ISSR markers. Genetics and Molecular Research, v.15, n.2, e15027997, 2015. https://doi.org/10.4238/ gmr. 15027997

BARBOSA, J.R.L.; RIGON, F.; CONTE, A.M.; SATO, O. Caracterização de atributos físicos de substratos para fins de produção de mudas. Cultivando o Saber, v.11, n.1, p.13-25, 2018.

BASTOS, C.A.; MENEGUZZO, T.E.C.; VAN DEN BERG, C. A taxonomic revision of the Brazilian species of Encyclia (Orchidaceae: Epidendroideae: Epidendreae). Phytotaxa, v.342, n.1, p.1-84, 2018. https://doi. org/10.11646/phytotaxa.342.1.1

CHASE, M.W.; CAMERON, K.M.; FREUDENSTEIN, J.V.; PRIDGEON, A.M.; SALAZAR, G.; VAN DEN BERG, C.; SCHUITEMAN, A. An updated classification of Orchidaceae. Botanical Journal of the Linnean Society, v.177, n.2, p.151174, 2015. https://doi.org/10.1111/boj.12234

DRONK, A.G.; SILVA, A.P.V.; CUQUEL, F.L.; FARIA, R.T. Desenvolvimento vegetativo de híbrido de orquídea em diferentes substratos. Semina: Ciências Agrárias, v. 33, n.6, p.2109-2114, 2012. https://doi.org/10.5433/1679$0359.2012 \mathrm{v} 33 \mathrm{n} 6 \mathrm{p} 2109$ 
EMPRESA BRASILEIRA DE PESQUISA AGROPECUÁRIA (EMBRAPA). Serviço Nacional de levantamento e Conservação de Solos. Manual de métodos de análises de solo. 2ed. Rio de Janeiro: Embrapa-CNPS, 1997.

FARIA, R.T.; STEGANI, V.; BERTONCELLI, D.J.; ALVES, G.A.C.; ASSIS, A.M. Substrates for the cultivation of epiphytic orchids. Semina: Ciências Agrárias, v.39, n.6, p.2851-2866, 2018. https://doi.org/10.5433/16790359.2018v39n6p2851

FERREIRA, D.F. Sisvar: a computer analysis system to fixed effects split plot type designs. Revista Brasileira de Biometria, v.37, n.4, p.529-535, 2019. https://doi. org/10.28951/rbb.v37i4.450

HOSHINO, R.T.; ALVES, G.A.C.; MELO, T.R.; BARZAN, R.R.; FREGONEZI, G.A.F.; FARIA, R.T. Adubação mineral e orgânica no desenvolvimento de orquídea Cattlianthe 'Chocolate drop'. Horticultura Brasileira, v.34, n.4, p.475482, 2016a. https://doi.org/10.1590/s0102-053620160405

HOSHINO, R.T.; COLOMBO, R.C.; ZANDONÁ, A.P.; ALVES, G.A.C.; FARIA, R.T. Organic fertilizer on the in vitro cultivation of the Cattleya labiata orchid. Agronomy Science and Biotechnology, v.2, n.2, p.62, 2016b. https:// doi.org/10.33158/ASB.2016v2i2p62

ICHINOSE, J.G.S.; MANTOVANI， C.; MAZZINIGUEDES, R.B.; PIVETTA, K.F.L.; FARIA, R.T.; VILLAS BOAS, R.L.; HOSHINO, R.T. Plant development and nutrient uptake rate in Dendrobium nobile Lindl. Journal of Plant Nutrition, v.41, n.15, p.1937-1945, 2018. https:// doi.org/10.1080/01904167.2018.1482913

KIM, H.J.; KIM, J.; YUN, D.L.; KIM, K.S.; KIM, Y.J. Growth and Flowering of Doritaenopsis Queen Beer 'Mantefon' as affected by different potting substrates. The Horticulture Journal, v.85, n.4, p.360-365, 2016. https:// doi.org/10.2503/hortj.MI-133

LONE, A.B.; BARBOSA, C.M.; TAKAHASHI, L.S.A.; FARIA, R.T. Acclimatization of Cattleya (Orchidaceae) on substrates alternative to xaxim and sphagnum. Acta Scientiarum. Agronomy, v.30, n.4, p.465-469, 2008. https://doi.org/10.4025/actasciagron.v30i4.5299

LUDWIG, F.; FERNANDES, D.M.; GUERREIRO, A.C.; VILLAS BOAS, R.L. Características dos substratos na absorção de nutrientes e na produção de gérbera de vaso Revista Horticultura Brasileira, v.32, n.2, p.184-189, 2014. https://doi.org/10.1590/S0102-05362014000200011
MEISEL, J.E.; KAUFMANN, R.S.; PUPULIN, F. Orchids of tropical America: an introduction and guide. London: Cornell University, 2014.

MENGARDA, L.H.G.; COLA, G.P.A.; OLIVEIRA, S.C.; FREITAS, A.R. Multiplication, rooting in vitro, and acclimatization of Brassavola tuberculata Hook. (Orchidaceae), an orchid endemic to the Brazilian Atlantic rainforest. Bioscience Journal, v.33, n.3, p.730-738, 2017. https://doi.org/10.14393/BJ-v33n3-32987

MIRANI, A.A.; ABUL-SOAD, A.A.; MARKHAND, G.S. Effect of different substrates on survival and growth of transplanted orchids (Dendrobium nobile cv.) into net house. International Journal of Horticulture and Floriculture, v.5, n.4, p.310-317, 2017.

NAIK, S.K.; BHARATHI, T.U.; BARMAN, D.; DEVADAS, R.; RAM, P.; MEDHI, R.P. Status of mineral nutrition of orchid: a review. Journal of Ornamental Horticulture, v.12, n.1, p.1-14, 2009.

PANSARIN, E.R.; PANSARIN, L.M. The family Orchidaceae in the Serra do Japi, state of São Paulo, Brazil. New York: Springer, 2010. 40 p.

SANTOS, M.R.A.; SMOZINSKI, C.V. Evaluation of different substrates on the acclimatization of Epidendrum ibaguense Kunth plantlets. Saber Científico, v.4, n.2, p.57$66,2015$.

SILVA, J.T.; HOSSAIN, M.M.; SHARMA, M.; DOBRÁNSZKI, J.; CARDOSO, J.C.; SONGJUN, Z. Acclimatization of in vitro-derived Dendrobium. Horticultural Plant Journal, v.3, n.3, p.110-124, 2017. https://doi.org/10.1016/j.hpj.2017.07.009

SOUSA, G.G.; ROSA, Y.B.C.J.; MACEDO, M.C.; SOARES, J.S. Aclimatização de Brassavola tuberculata com a utilização de ANA em diferentes substratos. Horticultura Brasileira, v.33, n.2, p.208-215, 2015. https://doi.org/10.1590/S0102-053620150000200012

TEJEDA-SATORIUS， O.; TREJO-TÉLLEZ， L.I.; TÉLLEZ-VELASCO, M.A.A.; GÓMEZ-MERINO, F.C. Nutrient concentration in vegetative organs of the orchid Laelia anceps subsp. anceps based on mineral fertilization and biofertilization. Horticulture Journal, v.87, n.4, p.541-548, 2018. https://doi.org/10.2503/hortj.OKD-148

VILLA, F.; PEREIRA, A.R.; PASQUAL, M.; ARAÚJO, A.G. Influência de substratos alternativos na aclimatização de orquídea. Revista Ceres, v.54, n.316, p.501-505, 2007. 